\title{
Assessment of Genistein and Daidzein Production By Some Local Fungal and Bacterial Isolates
}

\author{
Asmaa I. El-Shazly ${ }^{\#}$ Azza M. Noor El-Deen, Nevin A. Ibrahim*, Nayera A. M. \\ Abdelwahed, Ahmed A. El-Beih, Yousseria M. H. Shetaia*and Mohamed A. \\ Farid \\ Department of Chemistry of Natural and Microbial Products, National Research \\ Centre and *Department of Microbiology, Ain Shams University, Cairo, Egypt.
}

\begin{abstract}
TWENTY-THREE different bacterial and fungal isolates were grown and screened for their capability to transform soy glycosides to their aglycone forms with higher titer of antioxidant activity compared to unfermented soy flour. Most of the bacterial isolates showed higher amounts of daidzein than of genistein, which are the aglycone products of daidzin and genistin. After fermentation of soybean flour using bacterial and fungal isolates, the content of isoflavone aglycones varied from 0.0 to $431.89 \mu \mathrm{g} / \mathrm{g}$ compared to unfermented autoclaved soybean flour. Extracellular $\beta$-glucosidase activity was ranged from 1.22 to $11.56 \mathrm{mU} / \mathrm{mL}$ and $0.3-534.3 \mathrm{U} / \mathrm{mL}$ for bacterial and fungal isolates, respectively, while, bacterial cell-bound $\beta$-glucosidase ranged from 44.72 to $128.89 \mathrm{mU} / \mathrm{mL}$. Most of the bacterial isolates more efficiently transformed daidzin and genistin into the aglycones than fungal isolates. Among the tested bacterial isolates, the most potent one was selected, characterized according to the morphological and 16S rDNA sequence analysis and identified as Bacillus licheniformis NRC24.
\end{abstract}

Keywords: Daidzein, Genistein, $\beta$-glucosidase, free radical DPPH-scavenging activity, phylogentic tree, B. licheniformis NRC24.

\section{Introduction}

Elevated consumption of soybean products has been proposed to contribute to lowering the occurrence of chronic diseases, for example, atherosclerosis, cancer, osteoporosis and menopausal disorders. Different functional ingredients in soy-based food are of health benefits, especially isoflavones (Ewe et al., 2012). Soy isoflavones are mainly glucosides (malonyl, acetyl and $\beta$-glucosides) with a small amount of the more bioactive aglycones (Chun et al., 2008). The chemical structure of soy isoflavones influences their bioavailability and hence their biological and physiological efficiency. Highly polar and water-soluble glucosides are less absorbable by intestinal epithelium and thus have weaker biological activities than their respective counterpartswith the sugars removed (aglycones) (Ren et al., 2001). Fermenting soy flour by certain microorganisms has been shown to increase aglycone content conversion from their glucosides (Handa et al., 2014). Fermented soy products, like natto, tempeh and miso show higher antioxidant activity than unfermented soybeans (Murakami et al., 1984 and Berghofer et al., 1998).

Bacillus is one of the large genera of bacterial strains. It is a rod shaped, endospore bearing bacterium and belongs to the family Firmicutes. The genus Bacillus includes a great diversity of strains; some of them are strictly aerobic, while others are facultative anaerobic (Schallmey et al., 2004). B. licheniformis is a saprophytic bacterium found in nature and commonly found in soil and other natural environments. B. licheniformis is capable of growing on a large diversity of nutrient sources by means of synthesizing and secreting different hydrolytic enzymes and this quality makes it an industrially important microorganism (Raksha Rao et al., 2017 and Zhou et al., 2017).

In the current study, different bacteria and fungi were isolated from different soil samples and screened for daidzin and genistin biotransformation. The maximum daidzein and genistein transforming microbial isolate was identified using conventional and molecular techniques. 


\section{Materials and Methods}

Chemicals

Daidzein, genistein, 2, 2- diphenyl -1picrylhydrazyl (DPPH) and $p$-nitrophenyl $-\beta$-Dglucoside $(p$-NPG) were obtained from Sigma Company (St. Louis, MO, USA). Soybean (Glycine max) flour was purchased from the soybean unit, Agricultural Research Centre, Egypt. High-performance liquid chromatography (HPLC) grade methanol was purchased from Fisher Scientific (Hanover Park, IL). Nutrient agar medium was imported from Sisco Research Laboratories Pvt. Ltd, New Mumbai, India. Potato dextrose agar medium was imported from Laboratories Conda S.A., Madrid, Spain and a Gram's staining kit from Biodiagnostic, Giza, Egypt. All other chemicals used were of analytical grade.

\section{Media}

Isolation media was composed of agar $(25 \mathrm{~g} / \mathrm{L})$ supplemented and autoclaved separately with one of the following materials, $10 \mathrm{~g} / \mathrm{L}$ soybean flour (Medium No.1) and $2 \mathrm{~g} / \mathrm{L}$ cellobiose (Medium No.2). $\mathrm{pH}$ value was adjusted before autoclaving to 7 by adding $0.1 \mathrm{~N} \mathrm{NaOH}$ for bacterial isolation and to 6.0 by $0.1 \mathrm{~N} \mathrm{HCl}$ for fungal isolation. Screening medium was composed of defatted soybean flour, $10 \mathrm{~g} / \mathrm{L}$.

\section{Microorganisms}

Twenty-three local bacterial and fungal isolates from different soil samples were obtained from different locations in Egypt.

\section{Isolation of bacterial and fungal isolates}

Isolation of microorganisms was performed according to Stanbury et al. (1995). One gram of each soil sample was suspended in $10 \mathrm{~mL}$ of sterilized water, vortexed for $1 \mathrm{~min}$ and then sedimented. Each sample was serially diluted (till $\mathrm{X} 10^{-6}$ ) and $100 \mu \mathrm{L}$ of each dilution sample was streaked on poured agar medium (Medium No. 1 and Medium No. 2) in sterilized petri dishes (Jensen, 1968). For bacterial isolation, the inoculated plates were incubated at $37^{\circ} \mathrm{C}$ for $24 \mathrm{~h}$ while for fungal isolation; the plates were incubated at $28 \pm 2^{\circ} \mathrm{C}$ for $96 \mathrm{~h}$. All morphologically contrasting colonies were purified using streak plate method. The pure bacterial and fungal cultures were preserved in $20 \%$ glycerol vials at $-80^{\circ} \mathrm{C}$.

\section{Screening for biotransformation of soy isoflavone aglycones}

Bacterial and fungal isolates were screened for daidzin and genistin biotransformation according to the method reported by Tsangalis et al. (2002). Bacterial isolates were previously activated by subcultured to nutrient agar slants and incubated at $37^{\circ} \mathrm{C}$ for $24 \mathrm{~h}$ while fungal isolates were subcultured on potato dextrose agar medium and incubated at $28 \pm 2^{\circ} \mathrm{C}$ for $96 \mathrm{~h}$. Defatted soybean flour $(0.5 \mathrm{~g})$ was dispersed in $250 \mathrm{~mL}$ Erlenmeyer flasks with $50 \mathrm{~mL}$ distilled water and autoclaved at $121^{\circ} \mathrm{C}$ for $15 \mathrm{~min}$. Submerged fermentation was performed by evenly inoculating the autoclaved soybean substrate with $5 \mathrm{~mL}$ of cell suspension of the tested microbial isolates. The inoculated Erlenmeyer flasks were incubated under shaking culture at $200 \mathrm{rpm}$ at $37^{\circ} \mathrm{C}$ for $48 \mathrm{~h}$ and at $28 \pm 2^{\circ} \mathrm{C}$ for $96 \mathrm{~h}$ for bacterial and fungal isolates, respectively. $50 \mathrm{~mL}$ of uninoculated autoclaved defatted soybean flour medium was used as a negative control. At the end of incubation period, a $45 \mathrm{~mL}$ aliquot was taken from each flask and stored immediately at $-80^{\circ} \mathrm{C}$ for the analysis of isoflavones. The frozen aliquots were freeze dried using a freeze drier (Beta, Martin Christ Gefriertrocknungsanlagen $\mathrm{GmbH}$, Germany) for isoflavone extraction and analysed using reverse phase high-performance liquid chromatography (HPLC). A sample of $5 \mathrm{~mL}$ was analyzed for assessment of $\beta$-glucosidase activity using $p$-nitrophenyl- $\beta$-D-glucoside ( $p$-NPG) as the synthetic substrate.

Further screening with different concentrations of soybean flour was done according to Mukhtar \& Haq (2013). Different concentrations of defatted soybean flour $(10,20$ and $40 \mathrm{~g} / \mathrm{L})$ were tested for their efficiency in the biotransformation of daidzin and genistin to daidzein and genistein.

\section{Measurement of $\mathrm{pH}$}

The $\mathrm{pH}$ value of the aliquots after the fermentation was monitored using a $\mathrm{pH}$ meter (WalkLAB Microprocessor pH meter HP9000) after calibrating with fresh $\mathrm{pH} 4.0$ and 7.0 standard buffers.

\section{Assessment of $\beta$-glucosidase activity \\ Extracellular $\beta$-glucosidase activity}

$\beta$-glucosidase activity was determined using $p$-nitrophenyl- $\beta$-D-glucopyranoside as a substrate according to the method reported by Otieno $\&$ Shah (2007) with some modifications. The reaction mixture in a total volume of $1.5 \mathrm{~mL}$ was composed of $0.5 \mathrm{~mL}$ of $(0.1 \%) p$-nitrophenyl- $\beta$ $\mathrm{D}$-glucopyranoside in $(0.05 \mathrm{M})$ sodium phosphate buffer with $\mathrm{pH} 7$ (for bacterial samples) and $1 \mathrm{~mL}$ of the culture filtrate (as a source of extracellular

Egypt. J. Microbiol. 52 (2017) 
$\beta$-glucosidase enzyme). For fungal samples 0.05 $\mathrm{M}$ citrate buffer with $\mathrm{pH}$ value 5 was used. After $30 \mathrm{~min}$ of incubation at $37^{\circ} \mathrm{C}, 0.5 \mathrm{~mL}$ of $(1 \mathrm{M})$ cold sodium carbonate was added to stop the reaction. The aliquots were then placed in $2-\mathrm{mL}$ centrifuge tubes and subjected to centrifugation at $15000 \mathrm{rpm}$ for $30 \mathrm{~min}$ using an Eppendorf centrifuge (model 5415D; Eppendorf, Hamburg, Germany). The amount of $p$-nitrophenol released was measured using a spectrophotometer (SP2000UV, Spectra, USA) at a wavelength of 401 $\mathrm{nm}$. One unit of enzyme activity was defined as the amount of enzyme that would liberate $1 \mathrm{mmol}$ $p$-nitrophenol per minute under assay conditions.

\section{Cell-bound $\beta$-glucosidase activity}

The assay of cell-bound $\beta$-glucosidase activity was determined with the modified method of Kuo et al. (2006). $1 \mathrm{~mL}$ of culture broth was centrifuged at $15000 \mathrm{rpm}$ for $5 \mathrm{~min}$, then the supernatant was discarded and the cell pellets were washed with sodium phosphate buffer ( $\mathrm{pH}$ 7.0). The cell pellets were re-suspended in $0.5 \mathrm{~mL}$ of sodium phosphate buffer ( $\mathrm{pH}$ 7.0) containing 0.1\% $p$-nitrophenyl$\beta$-D-glucoside $\left(P\right.$-NPG) and incubated at $37^{\circ} \mathrm{C}$ for $30 \mathrm{~min}$. The reaction was stopped by adding of $0.5 \mathrm{~mL}(1 \mathrm{M}) \mathrm{Na}_{2} \mathrm{CO}_{3}$ and centrifuged at $15000 \mathrm{rpm}$ for $10 \mathrm{~min}$. This reaction supernatant was measured using a spectrophotometer (SP2000UV, Spectra, USA) at a wavelength of 401 $\mathrm{nm}$. The amount of released $p$-nitrophenol was measured as described before.

\section{Extraction of isoflavones}

The extraction of isoflavones, including daidzein and genistein from fermented and unfermented soybean flour, was performed using a modified version of the method described by Fukutake et al. (1996). $1 \mathrm{~g}$ of freeze-dried sample was added to 10 $\mathrm{mL}$ of $80 \%(\mathrm{v} / \mathrm{v})$ aqueous methanol and extracted under agitation for $24 \mathrm{~h}$ at room temperature. The homogenates were centrifugated at $15000 \mathrm{rpm}$ for $30 \mathrm{~min}$ and the obtained methanolic extracts were used to determine daidzein and genistein and antioxidant activity.

Assessment of the antioxidant activity DPPH free radical-scavenging assay

The ability of the isoflavone extracts to scavenge DPPH (2, 2-diphenyl-1-picrylhydrazyl) free radicals was assessed spectrophotometrically (Pyo et al., 2005). A $20 \mu \mathrm{L}$ aliquot of each isoflavone extract was mixed in a test tube with $1.0 \mathrm{~mL}$ methanol containing $(0.1 \mathrm{mM}) \mathrm{DPPH}$, which is a stable free radical, and has a typical absorbance at $517 \mathrm{~nm}$. The decrease in absorbance at $517 \mathrm{~nm}$ was measured at $100 \mathrm{~min}$. The decreased absorbance of DPPH was calculated by the following equation:

Scavenging activity $(\%)=\mathrm{AA} \%=100-\left[\left(\mathrm{Abs}_{\text {sample }}\right.\right.$ $\left.\left.-\mathrm{Abs}_{\text {blank }}\right) \times 100 / \mathrm{Abs}_{\text {control }}\right]$

where $\mathrm{Abs}_{\text {control }}$ is the absorbance of the DPPH solution without addition of the sample; $\mathrm{Abs}_{\text {sample }}$ is the absorbance of the mixture solution containing both the sample and DPPH, and $\mathrm{Abs}_{\text {blank }}$ is the absorbance of the blank solution without DPPH.

\section{HPLC analysis of isoflavones}

HPLC instrument Young Lin (Young Lin Cooperation, Seoul, South Korea) consists of a Reprosil-Pur Basic C18 5 $4 \mathrm{~m}$ (dimension: 250 $\times 4.6 \mathrm{~mm})$ column and a UV detector $(\lambda \max$ $=210 \mathrm{~nm}$ ). Isocratic elution was used to isolate the isoflavones for detection. The mobile phase consisted of $100 \%$ methanol and $10 \mathrm{mmol} / \mathrm{L}$ of ammonium acetate buffer (60: 40) containing $1 \mathrm{~mL}$ of trifluoro-acetic acid per litre of solvent mixture. This was set at a flow rate of $1 \mathrm{~mL} / \mathrm{min}$ according to the method by Otieno \& Shah (2007) with some modifications. Injection volumes of isoflavone standards and of the samples were set at $100 \mu \mathrm{L}$ throughout the run time of $30 \mathrm{~min}$. Single standards were prepared for peak identification. Isoflavone concentrations were calculated back to dry basis ( $\mu \mathrm{g} / \mathrm{g}$ soybean flour).

\section{Calibration curves of Isoflavone standard}

Soy isoflavone aglycones were quantified by analysing each methanolic standard of dadzein and genistein by HPLC using a diode array detector (HPLC-DAD), following the procedure described by da Silva et al. (2011). Standard solutions of known concentrations of daidzein $(0.25,0.5,0.75$, $1.25,2.5$ and $5 \mu \mathrm{g} / \mathrm{mL})$ and genistein $(0.5,1,2$, 3,4 and $5 \mu \mathrm{g} / \mathrm{mL}$ ) were used. The areas obtained were matched to their respective concentrations. The concentrations of daidzein and genistein were calculated by interpolation of the areas and expressed in $\mu \mathrm{g}$ of each isoflavone aglycone per gram of soybean flour, on a dry weight basis. The isoflavone peaks were identified by a comparison of the retention times (RT) and confirmed by a comparison of the UV spectra with those of the reference materials.

Identification of the most potent bacterial isolate

The identification of the most potent bacterial isolate was performed on the basis of morphological and molecular characteristics. 


\section{Morphological characterization}

Cultural characteristics such as colony morphology (color, shape, margin and surface) and cell morphology (shape, Gram reaction, and arrangement) of the selected bacterial isolate were carried out according to Bergey \& Holt (1994) by using a bright field microscope (Olympus CX41RF, Olympus cooperation, Tokyo, Japan).The selected bacterial isolate was characterized by Gram's stainingand results of the staining procedure were observed under oil immersion lens (100x).

\section{Molecular approach \\ DNA extraction and PCR amplification of $16 S$ rDNA}

QIAamp mini kit (QIAGEN) was used for DNA extraction according to the procedure of manufacturer. The total DNA was eluted in $50 \mu \mathrm{L}$ of AE buffer and stored at $-80{ }^{\circ} \mathrm{C}$ until used. PCR was performed in a reaction volume of $50 \mu \mathrm{L}$, consisting of $0.2 \mathrm{mM}$ each dNTP (Invitrogen), $0.4 \mathrm{M}$ each primer, $5 \mu \mathrm{L} 10 \mathrm{X}$ PCR buffer (Promega), $1.5 \mathrm{mM} \mathrm{MgCl}$ and $1 \mathrm{U}$ Taq DNA polymerase (Promega). The universal primer pairs used to amplify bacterial $16 \mathrm{~S}$ rDNA were $27 \mathrm{f}$ (59-AGAGTTTGATCCTGGCT CAG-39) and 1492r (59-GGTTACCTTGTTACGACTT-39) (Lane et al., 1985). PCR amplification was performed with 30 cycles as follows: denaturation at $94^{\circ} \mathrm{C}$ for $1 \mathrm{~min}$, annealing at $55^{\circ} \mathrm{C}$ for $1 \mathrm{~min}$ and extension at $72{ }^{\circ} \mathrm{C}$ for $2 \mathrm{~min}$. Amplification products were separated by $1.0 \%$ agarose gel electrophoresis and visualized under UV light.

\section{Sequencing of $16 \mathrm{~S}$ rDNA}

The PCR products were separated by $(1 \%)$ agarose gel electrophoresis. Amplicons of the appropriate sizes were subsequently excised from the gel and purified using QIAGEN gel extraction kit (Qiagen, Hilden, Germany). The purified PCR products were directly used for cycle sequencing reactions using BigDyeR Terminator v3.1 Cycle Sequencing Kit (Applied Biosystems, Foster City, $\mathrm{CA}$ ) according to the manufacturer's instructions, and were further amplified for 26 cycles at $95^{\circ} \mathrm{C}, 30$ $\mathrm{s} ; 50^{\circ} \mathrm{C}, 15 \mathrm{~s} ; 60^{\circ} \mathrm{C}, 4 \mathrm{~min}$. The reaction product was purified by exclusion chromatography in CentriSep columns (Princeton Separations, Adelphia, NJ). The recovered materials were sequenced using an $\mathrm{ABI}$ 3730XLDNA analyzer (Applied Biosystems, Foster City, CA). Sequences were generated using SeqMan DNA Lasergene 7 software (DNASTAR, Madison, WI).

Phylogenetic analysis of the selected bacterial isolate

Phylogenetic analysis was done using the neighbor-joining algorithm with the Kimura 2-parameter model. Vibrio rotiferianus was used as an out-group and used as the root for the tree. The reliability of phylogenetic inference at each branch node was estimated by the bootstrap method with 1000 replications, evolutionary analysis was conducted in MEGA6.

\section{Results}

Isolation and screening of some Egyptian bacterial and fungal isolates for the biotransformation of soy glucosides into soy aglycones

Screening of the twenty-three microbial isolates was conducted to detect their ability to deglycosylate daidzin and genistin into daidzein and genistein using submerged fermentation.

The data recorded in Table 1 demonstrated that the bacterial isolate No. 3 was the most potent daidzein and genistein producer $(176.05,255.84$ $\mu \mathrm{g} / \mathrm{g}$, respectively), while the other microbial isolates produced daidzein and genistein in a range from 0.0 to 162.59 and from 1.32 to $149.67 \mu \mathrm{g} / \mathrm{g}$, respectively. The HPLC analysis of the fermented and unfermented samples revealed an increase of the aglycones forms for some tested microbial isolates (Fig. 1 a-d).

For bacterial isolates, it was noticed that the amount of daidzein was almost greater than that of genistein except for isolates No.3, 4 and 8 .

Few fungal isolates could transform isoflavone glycosides under the conditions used. Meanwhile, some fungal isolates were more potent producers of $\beta$-glucosidase than bacterial isolates. Bacterial isolates produced extracellular $\beta$-glucosidase with activity of $11.56 \mathrm{mU} / \mathrm{mL}$ and a cell-bound form with activity ranging from 44.72 to $128.89 \mathrm{mU} / \mathrm{mL}$, while fungal isolates produced extracellular $\beta$-glucosidase with activity ranged from 0.30 to $534.32 \mathrm{U} / \mathrm{ml}$. The highest extracellular $\beta$-glucosidase activity was produced by fungal isolate No. 9 .

Concerning the DPPH scavenging activity, all the tested microbial isolates exhibited enhanced antioxidant activity in all fermented soybean extracts compared to unfermented controls (Fig. 2). In case of bacterial isolates, the scavenging DPPH free radical activity ranged from $32.56 \%$ to $93.26 \%$, while, fungal isolates showed scavenging DPPH free radical activity ranging from $36.44 \%$ to $96.59 \%$. The highest values of DPPH free radical scavenging activity were obtained with bacterial isolates No. 1 and 5 and fungal isolates No. 6, 7 and 8, while bacterial isolate No. 6 and fungal isolate No. 11 showed the lowest DPPH scavenging activity. On the other hand, the unfermented soybean flour 
extract showed a scavenging activity of $25.04 \%$ for DPPH free radicals.

The $\mathrm{pH}$ values increased from 7.0 to 8.97 after soybean flour fermentation time (48 h) using bacterial isolates and increased from 5.0 to 9.26 after soybean flour fermentation time ( $96 \mathrm{~h}$ ) using fungal isolates (Table 1) except for fungal isolates No. 6 and 8, where the final $\mathrm{pH}$ shifted to acidic range 3.58 and 5.94 .

Among the candidates, bacterial isolates No. 3 and 8 had the ability to effectively transform daidzin and genistin into their aglycone forms, so, screening with different concentrations of soybean flour was investigated for both isolates. The changes in total isoflavone aglycones content after defatted soybean flour fermentation are summarized in Fig. 3. The isoflavone aglycones content (daidzein and genistein) of the fermented soybean flour using bacterial isolate No. 3 reached 289.03, 316.37 and $323.55 \mu \mathrm{g} / \mathrm{g}$ after $24 \mathrm{~h}$ of fermentation of different soybean flour concentrations; 10,20 and $40 \mathrm{~g} / \mathrm{L}$, respectively. Meanwhile, the total isoflavone content reached to 422.56, 233.35 and $207.21 \mu \mathrm{g} / \mathrm{g}$, respectively after $48 \mathrm{~h}$. Relating to bacterial isolate No. 8, the isoflavone aglycones content reached 198.57, 302.36 and 328.98 and 276.45, 209.41 and $257.76 \mu \mathrm{g} / \mathrm{g}$ after $24 \mathrm{~h}$ and $48 \mathrm{~h}$ at soybean flour concentration of $10,20 \& 40 \mathrm{~g} / \mathrm{L}$, respectively.

TABLE 1. Quantitative determination of daidzein and genistein production by selected bacterial and fungal isolates.

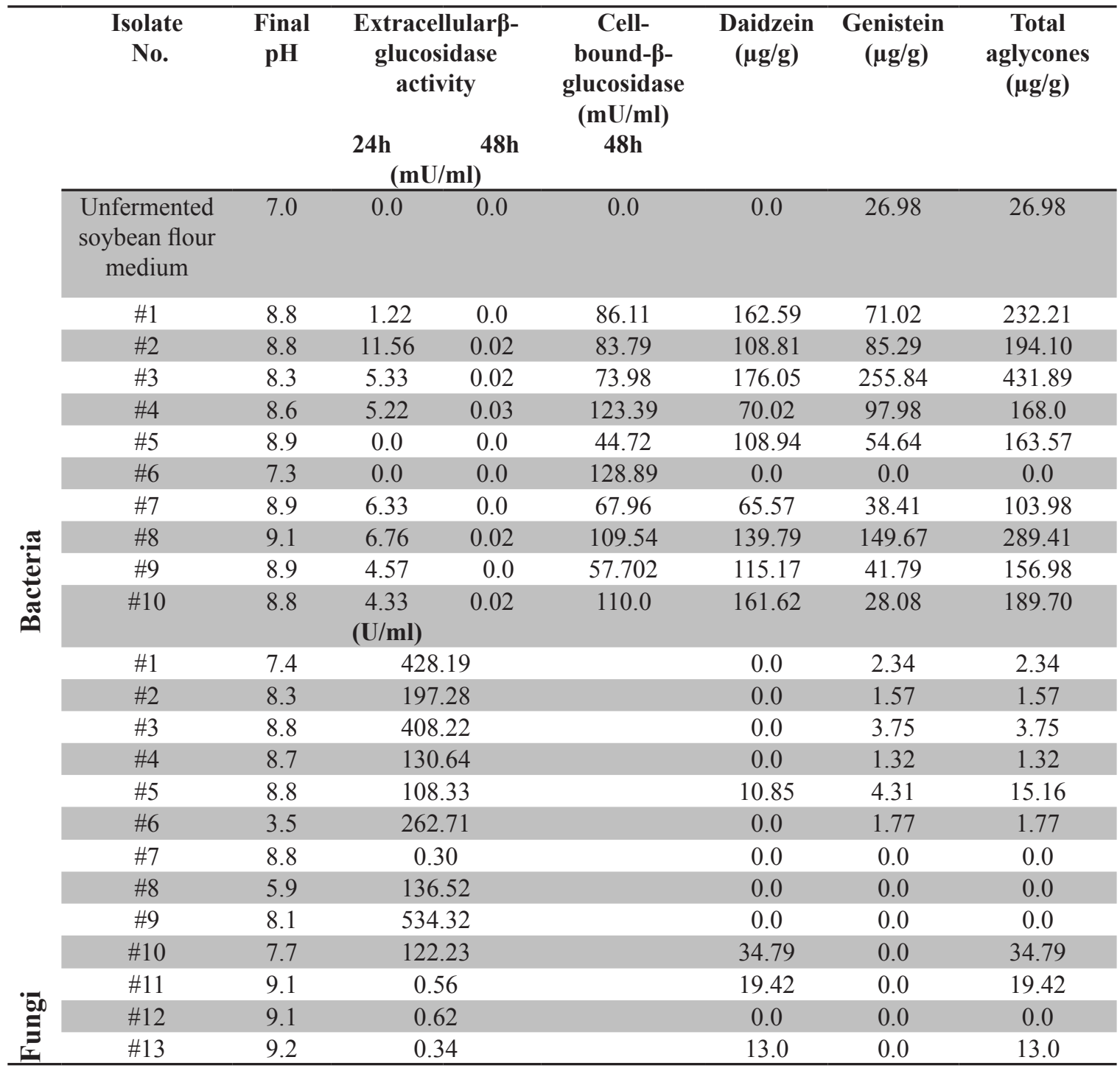




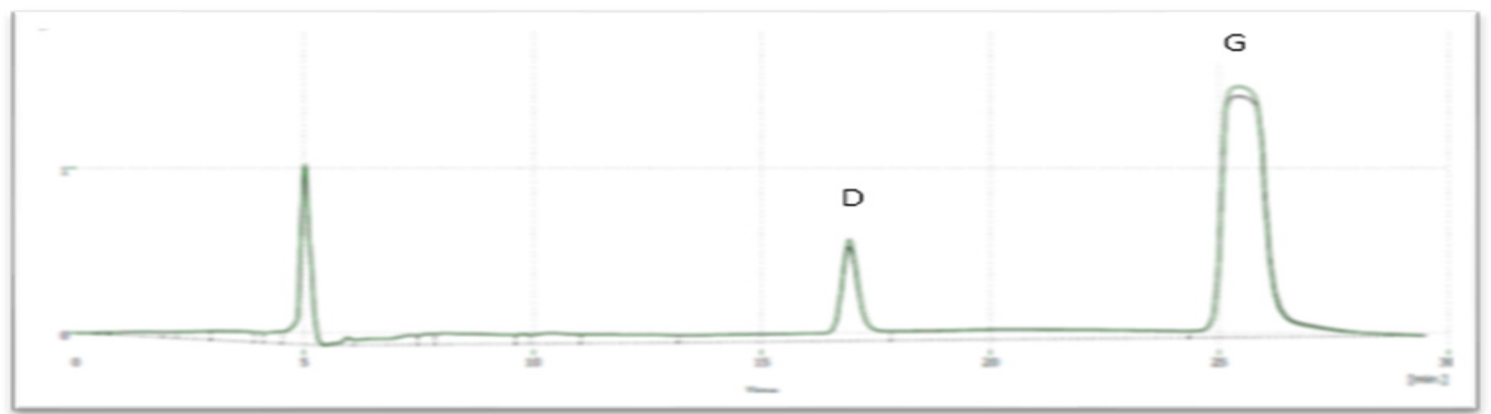

a

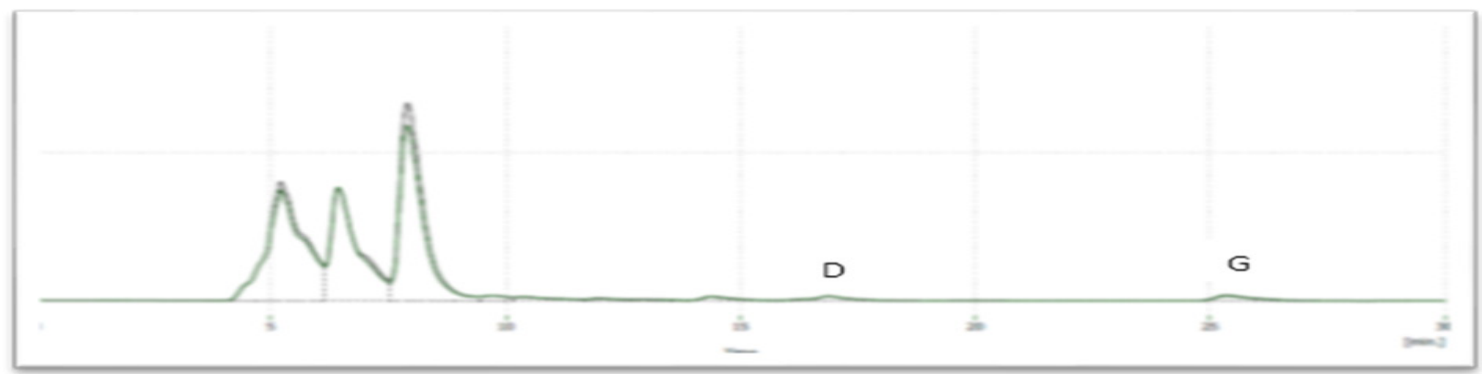

b

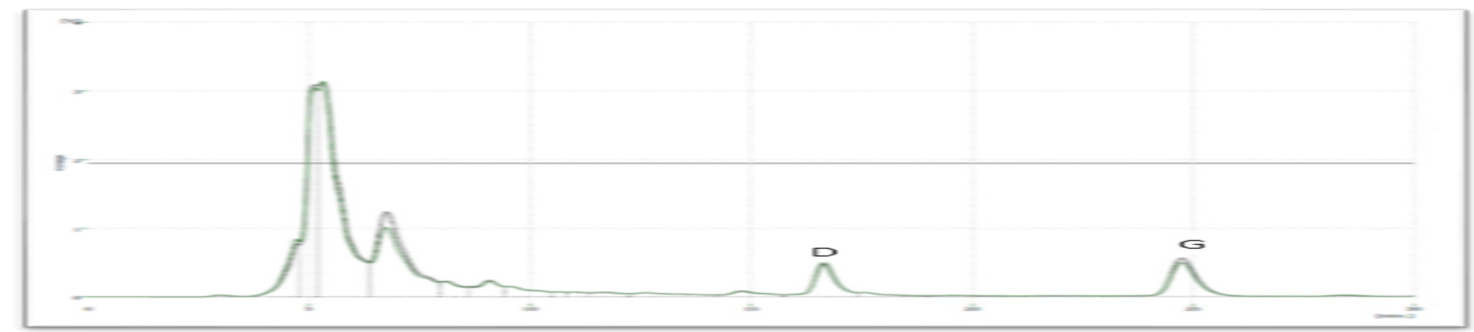

c

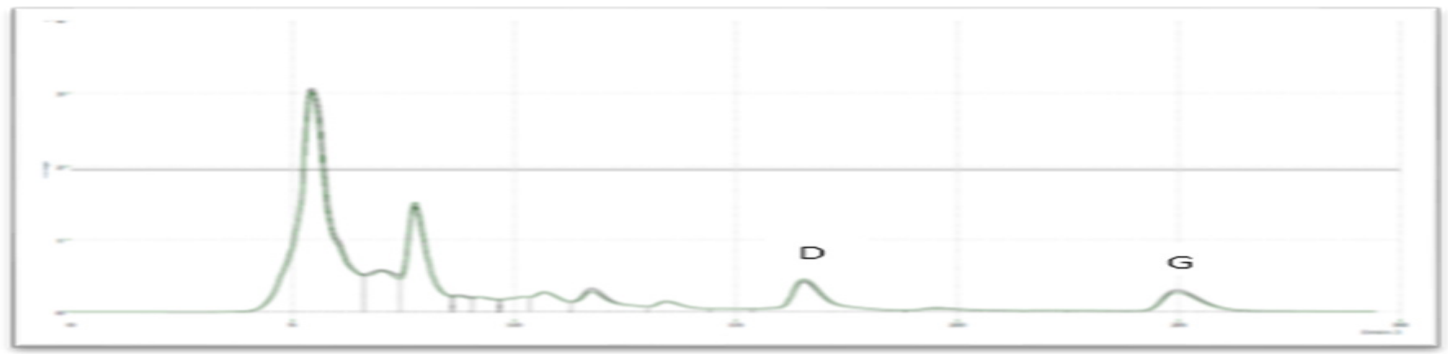

d

Fig. 1. HPLC chromatogram showing the retention times of (a) standard daidzein (D) followed by genistein (G), (b) unfermented soybean flour, (c) bacterial isolate No. 3 (d) bacterial isolate No. 8. 


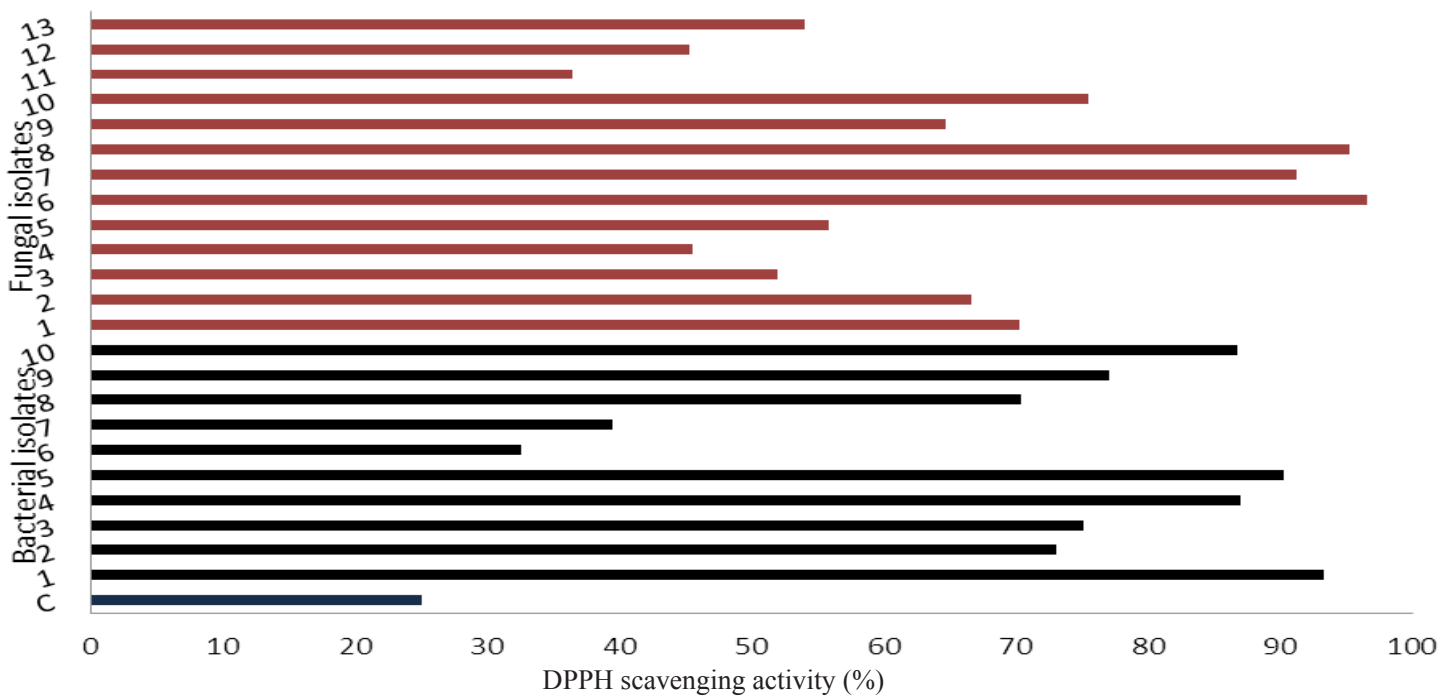

Fig. 2. Free radical DPPH scavenging activity (\%) of unfermented and fermented soybean by bacterial and fungal isolates.

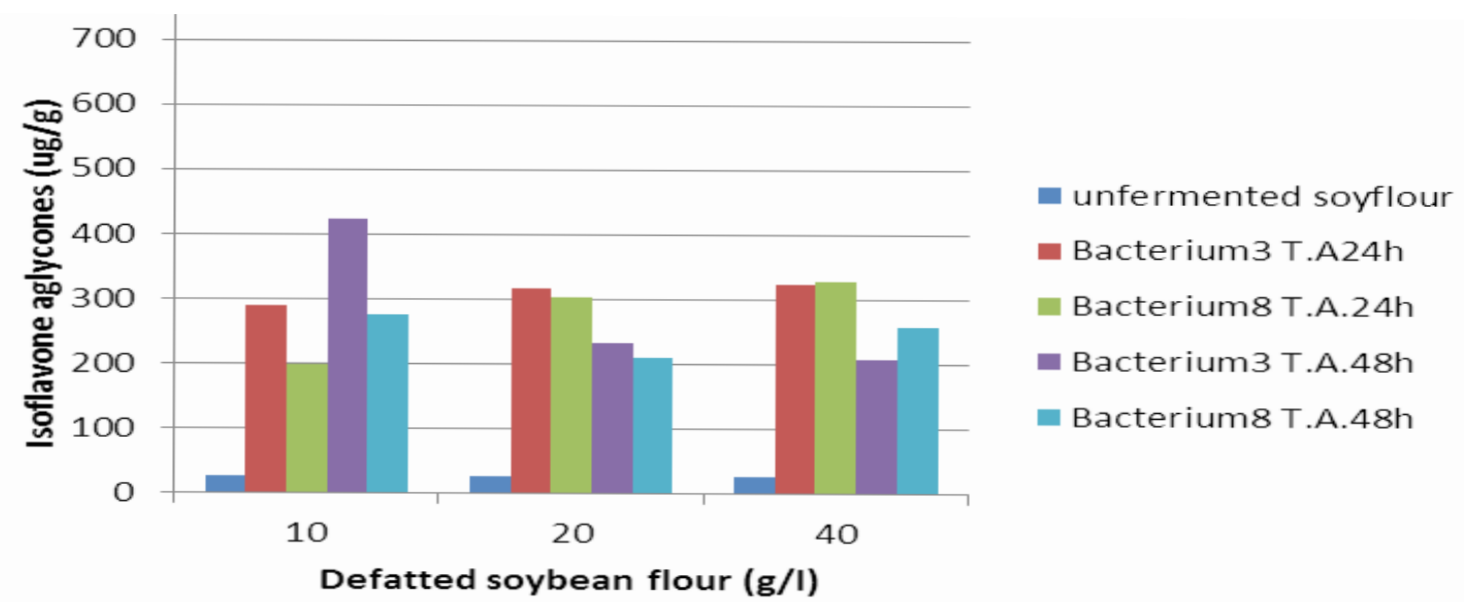

Fig. 3. Changes in isoflavone aglycones content at $24 \mathrm{~h}$ and $48 \mathrm{~h}$ submerged fermentation of defatted soybean flour by bacterial isolate No.3 and 8 .

Identification of the most potent bacterial isolate

The identification of the selected bacterial isolate was done on the basis of morphological and $16 \mathrm{~S}$ rDNA sequence analysis.

\section{Morphological characterization}

On the basis of morphological characteristics, the selected isolate was Gram stain positive (Fig. 4). Additionally, under microscopic examination, the cells appeared rods with rounded ends and the spores were lateral and cylindrical in shape. Cells appeared adherent, finely wrinkled, dull and opaque when cultivated on nutrient agar medium.

\section{Molecular characterization}

The genomic DNA of bacteria isolate No. 3 was extracted and 16S rDNA was amplified by PCR. The PCR product was examined by agarose gel electrophoresis. The PCR product was purified and sequencing was done in triplicate in order to get the correct sequence. The nucleotide sequence of $16 \mathrm{~S}$ rDNA was submitted in GenBank database under the accession number KX712228. The $16 \mathrm{~S}$ rDNA sequence of the bacterial isolate was aligned with all available 16S rDNA sequences in GenBank database and finally the phylogenetic tree was constructed (Fig.5). The phylogenetic tree indicated that this bacterial isolate belonged to the genus Bacillus and the pattern of the tree determined that the strain is closely related to other $B$. licheniformis strains with 99\% 16S rDNA similarity. 


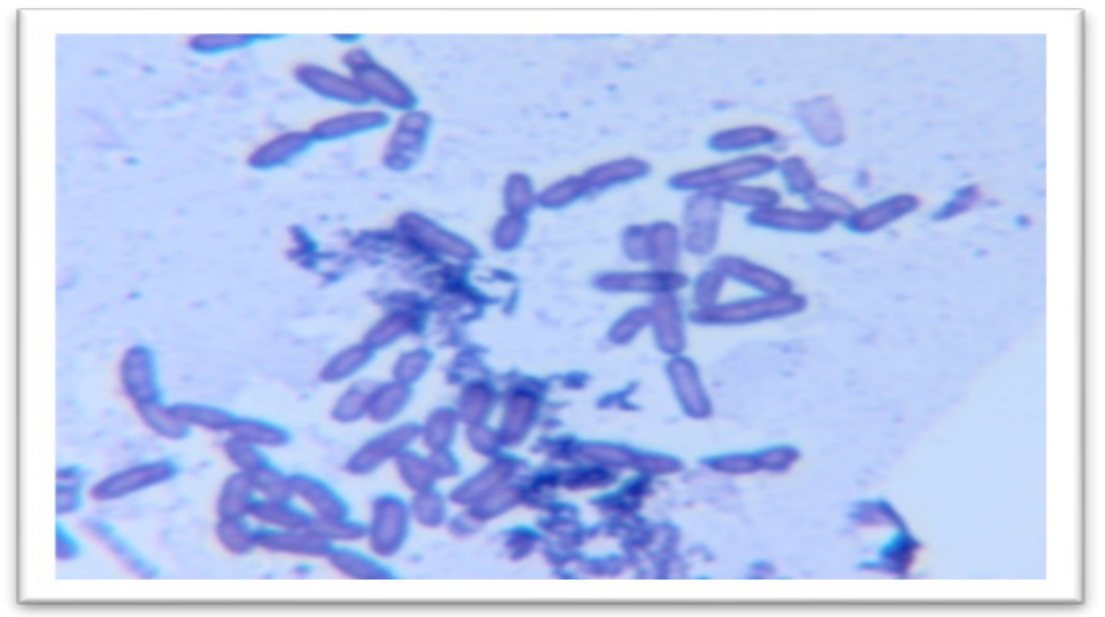

Fig. 4. Gram staining of bacterial isolate No. 3.

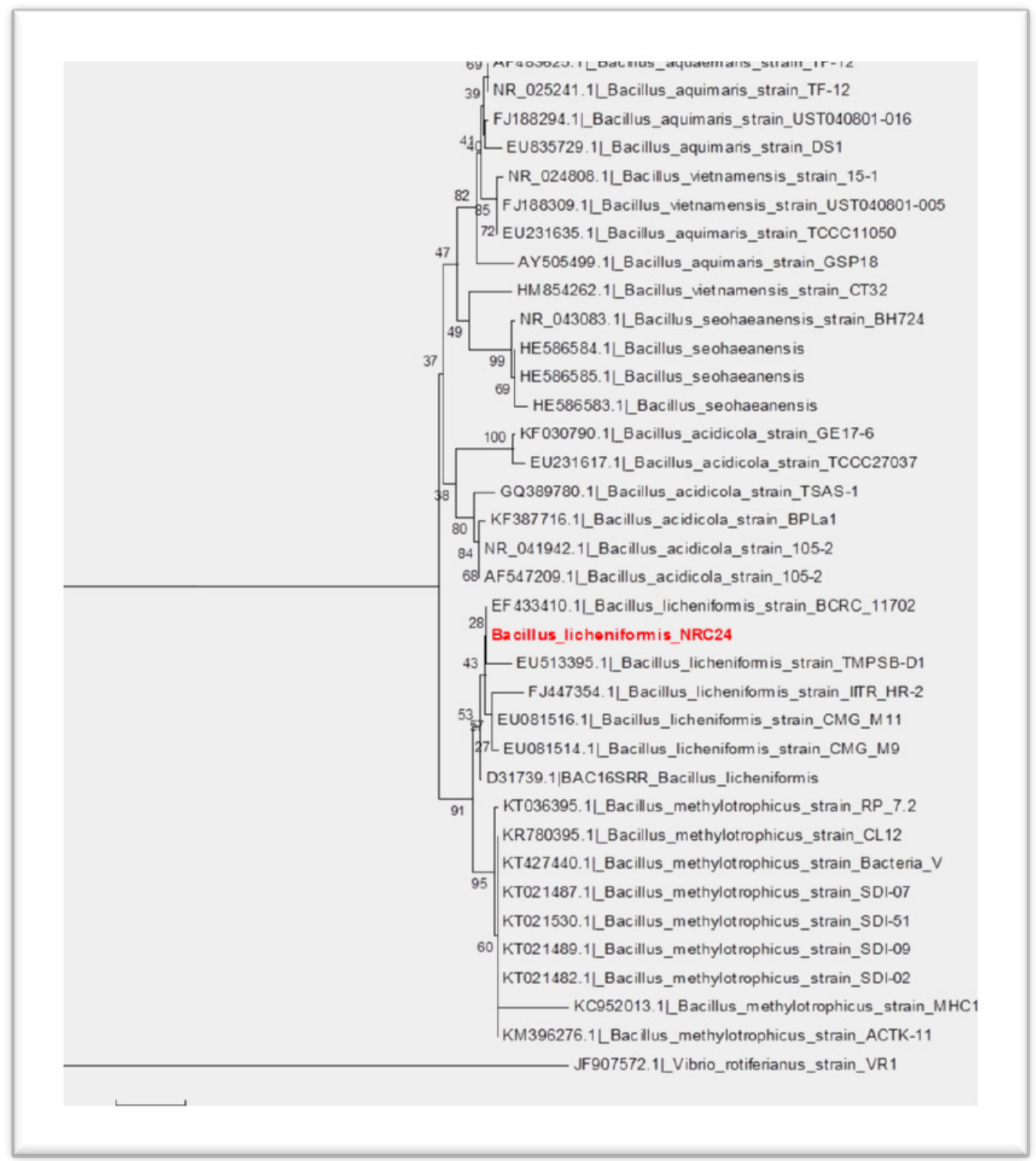

Fig. 5. Phylogentic tree showing the relation of B. licheniformis NRC24 with other species. 


\section{Discussion}

$\beta$-glucosidases are prevalent enzymes that hydrolyze broad glycosides including aryl and alkyl- $\beta$-d-glycosides. These enzymes, produced by many microorganisms, may also hydrolyse $\beta$-glucosidic linkages of soybean polyphenol $\beta$-glucosides mobilizing the polyphenol aglycones (Vong et al., 2016; Berrin et al., 2003 and Wolosowska \& Synowiecki, 2004).

Some microbial species were isolated based on the selection of the desired character (Stanbury et al., 1995). The growth of the bacterial and fungal isolates on cellobiose agar or defatted soybean flour agar showed that they were able to utilize cellobiose and soybean flour.

Most of the bacterial isolates efficiently hydrolyzed daidzin and genistin. Even if wide differences in the biotransformation of both daidzin and genistin were found, only one bacterial isolate (isolate No. 6) was incapable to perform the biotransformation of both daidzin and genistin. Variation in individual isoflavone contents as affected by different bacterial strains, Lactobacillus plantarum B1-6, Streptococcus thermophilus S10, Bacillus subtilis CSY191 were reported by Xiao et al. (2015), Lee et al. (2015) and Shin et al. (2014).

In fermented soybean flour, the isoflavone aglycone, daidzein, was found in larger amounts than that of genistein for almost all bacterial isolates, except isolates No. 3, 4 and 8 compared to unfermented soybean flour. Our results are in agreement with previous work for Bacillus spp. (Wei et al., 2008). The selective action of the $\beta$-glucosidase synthesized by most of the tested bacterial isolates on daidzin, could explain higher increase in the concentration of the product, daidzein, than that of genistein. That finding was also reported by Shin et al. (2014) and Kuo et al. (2012).

Some tested bacterial isolates did not produce extracellular $\beta$-glucosidase as their supernatants did not hydrolyze $p$-PNG, but all bacterial isolates showed positive cell-bound enzyme, which indicates that hydrolytic activity of the tested bacterial isolates mainly functions via cell-bound $\beta$-glucosidase activity. These results are similar to those reported by Raimondi et al. (2009), Tsangalis et al. (2002), Kuo et al. (2006) and Otieno \& Shah (2007). $\beta$-glucosidases produced intracellularly by many microorganisms usually show broad substrate specificity (Wolosowska \& Synowiecki,
2004) and their physiological functions vary greatly depending upon their origin and substrate specificity (Berrin et al., 2003).

Among the screened bacterial isolates, the level of DPPH radical-scavenging activity increased from 1.3 to 3.47 fold compared to unfermented soybean flour. The changes in isoflavone aglycones had a great effect on improving DPPH radicalscavenging activities of fermented soybean flour using bacterial isolates. The observed variations in scavenging activities may depend on various factors, including differences in the population of bacteria, strain type and the ratio of aglycones to glucosides. Genistein and daidzein have direct free radical scavenging ability (Lee et al., 2015 and Shon et al., 2007).

The fungal isolates produced more extracellular $\beta$-glucosidases than those obtained by bacterial isolates during soybean flour fermentation. These results are in accordance with that reported by Georgetti et al. (2009). That difference could be related to the cellular localization of the synthesized $\beta$-glucosidase or to the culture conditions. Bacterial synthesized $\beta$-glucosidases can be bound to the cell wall or secreted into the periplasmic space (Pyo et al., 2005). Soybean flour fermented by the tested bacterial isolates resulted in a greater biotransformation of daidzin and genistin into daidzein and genistein than that fermented by the tested fungal isolates. Fungal isolates No. 5, 10,11 and 13 only had the capability to transfom daidzin into daidzein. Yang et al. (2009) repoted that there are differences in hydrolysis of soybean isoflavones by microbial $\beta$-glucosides, which depend on their specificity towards various chemical forms of isoflavones. These results were related to substrate specificity of the produced enzyme that influencing the biotransformation of daidzin and genistin. Similarly, $\beta$-glucosidases produced by most our fungal isolates were still not able to hydrolyse $\beta$-glycosidic linkages of the isoflavonoids daidzin and genistin.

Although the methanolic extracts prepared from fermented soybean flour using fungal isolates presented higher scavenging activity (increased from 1.39 to 3.69 fold) than that of unfermented extract, they showed poor daidzein and genistein content. Thus, other phenolic compounds may be mobilized by fermentation and probably they are good hydrogen donor to the DPPH radicals as described by Georgetti et al. (2009). Additionally, Fan et al. (2009) mentioned that peptides and 
amino acids were liberated during douchi (a traditional fermented soybean product in China) fermentation, and that the antioxidant activity of the douchi depended on the increase in peptides with fermentation, rather than on the increase in isoflavone aglycons. Besides isoflavones and lowmolecular-weight peptides, soybean fermentation also produced other materials, such as amino acids and melanoidin, which can also cause changes in the antioxidant activities of fermented foods. Amino acids obtained during soybean fermentation can increase the antioxidant activity of tempeh, another fermented soybean food (Hoppe et al., 1997).

The $\mathrm{pH}$ values increased during soybean flour fermentation using bacterial and fungal isolates except for two fungal (Aspergillus niger) isolates No. 6 and 8. That rise in $\mathrm{pH}$ values was presumably a result of proteolysis and the release of ammonia following the use of amino acids by the fermenting microorganisms. The release of ammonia is responsible for the ammonia-like odor characteristic of most vegetable protein fermentations (Cho et al., 2009; Cho et al., 2011; Kim et al., 2012 and Shin et al., 2014).

Combined results suggested that bacterial isolates No. 3 and 8 synthesized $\beta$-glucosidases with higher specificity to hydrolyse daidzin and genistin $\beta$-glycosidic bonds than those produced by the other tested isolates. Additionally, their fermented methanolic extracts showed an increase in antioxidant activities. However, bacterial isolate No. 3 showed an efficient potency at different concentrations of soybean flour in transforming daidzin and genistin into their aglycone forms other than the tested bacterial isolate No. 8. As a result, bacterial isolate No. 3 was adopted as the working isolate for soy isoflavone glycosides biotransformation.

On the basis of morphological characteristics and $16 \mathrm{~S}$ rDNA sequence analysis, the bacterial isolate No.3 was identified as B. licheniformis $N R C 24$. The sequences of the current isolate were found to be $99 \%$ similar to $16 \mathrm{~S}$ rDNA sequences of $B$. licheniformis from various sources in GenBank database. It is not only $B$. licheniformis NRC24 that can produce $\beta$-glucosidase during soybean fermentation; other microorganisms used for fermented soybeans such as lactic acid bacteria and Bifidobacteria with soymilk (Chun et al., 2007 and 2008), Actinomucor elegans with sufu (Yin et al., 2004 and 2005), Rhizopus with tempeh (Miura et al., 2002), Aspergillus with miso (Yamabe et al., 2007), and B. subtilis with natto (Dajanta et al., 2009).

Acknowledgement: This work was supported by the National Research Center, Chemistry of Natural and Microbial Products Department and Ain Shams University, Faculty of Science, Microbiology Department, Egypt.

\section{References}

Bergey, D.H. and Holt, J.G. (1994) "Bergey's Manual of Determinative Bacteriology": Williams \& Wilkins.

Berghofer, E., Grzeskowiak, B., Mundigler, N., Sentall, W.B. and Walcak, J.J. (1998) Antioxidative properties of faba bean-, soybean- and oat tempeh. International Journal of Food Science and Nutrition, 49, 45-54.

Berrin, J.G., Czjzek, M., Kroon, P.A., McLauchlan, W.R., Puigserver, A., Williamson, G. and Juge, N. (2003) Substrate (aglycone) specificity of human cytosolic beta-glucosidase. The Biochemical Journal, 373, 41-48.

Cho, K.M., Hong, S.Y., Math, R.K., Lee, J.H., Kambiranda, D.M., Kim, J.M., Islam, S.M.A., Yun, M.G., Cho, J.J., Lim, W.J. and Yun, H.D. (2009) Biotransformation of phenolics (isoflavones, flavanols and phenolic acids) during the fermentation of cheonggukjang by Bacillus pumilus HY1. Food Chemistry, 114(2), 413-419.

Cho, K.M., Lee, J.H., Yun, H.D., Ahn, B.Y., Kim, H., and Seo, W.T. (2011) Changes of phytochemical constituents (isoflavones, flavanols, and phenolic acids) during cheonggukjang soybeans fermentation using potential probiotics Bacillus subtilis CS90. Journal of Food Composition and Analysis, 24(3), 402-410.

Chun, J., Kim, G.M., Lee, K.W., Choi, I.D., Kwon, G.H., Park, J.Y., Jeong, S.J., Kim, J.S. and Kim, J.H. (2007) Conversion of isoflavone glucosides to aglycones in soymilk by fermentation with lactic acid bacteria. Journal of Food Science, 72, 39-44.

Chun, J., Kim, J.S. and Kim, J.H. (2008) Enrichment of isoflavone aglycones in soymilk by fermentation with single and mixed cultures of Streptococcus infantarius 12 and Weissella sp. 4. Food Chemistry, 109, 278-284.

Dajanta, K., Chukeatirote, E., Apichartsrangkoon, A. and Richard, A. (2009) Enhanced aglycone production of fermented soybean products by Bacillus species. Acta Biologica Szegediensis, 53, 93-98. 
da Silva, L.H., Celeghini, R.M.S. and Chang, Y.K. (2011) Effect of the fermentation of whole soybean flour on the conversion of isoflavones from glycosides to aglycones. Food Chemistry, 128(3), 640-644.

Ewe, J.A., Wan Abdullah, W.N., Bhat, R., Karim, A. A. and Liong, M.T. (2012) Enhanced growth of lactobacilli and bioconversion of isoflavones in biotin-supplemented soymilk upon ultrasoundtreatment. Ultrason Sonochem, 19(1), 160-173.

Fan, J., Zhang, Y., Chang, X., Saito, M. and Li, Z. (2009) Changes in the radical scavenging activity of bacterial-type Douchi, a traditional fermented soybean product, during the primary fermentation process. Bioscience, Biotechnology, and Biochemistry, 73, 2749-2753.

Fukutake, M., Takahashi, M., Ishida, K., Kawamura, H., Sugimura, T. and Wakabayashi, K. (1996) Quantification of genistein and genistin in soybeans and soybean products. Food Chem Toxicol. 34(5), 457-461.

Georgetti, S.R., Vicentini, F.T., Yokoyama, C.Y., Borin, M.F., Spadaro, A.C. and Fonseca, M.J. (2009) Enhanced in vitro and in vivo antioxidant activity and mobilization of free phenolic compounds of soybean flour fermented with different betaglucosidase-producing fungi. Journal of Applied Microbiology, 106, 459-466.

Handa, C.L., Couto, U.R., Vicensoti, A.H., Georgetti, S.R. and Ida, E.I. (2014) Optimisation of soy flour fermentation parameters to produce betaglucosidase for bioconversion into aglycones. Food Chem. 152, 56-65.

Hoppe, M.B., Jha, H.C. and Egge, H. (1997) Structure of an Antioxidant from Fermented Soybeans (Tempeh). Journal of the American Oil Chemists' Society, 74, 477-479.

Jensen, V. (1968) The plate count method, In: The Ecology of Soil Bacteria. Gray TRG and Parkinson D (Ed.), An International Symposium, Liverpool University Press, Liverpool pp. 158-170.

Kim, M.H., Han, S.Y., Ko, J.M. and Kim, Y.S. (2012) Degradation characteristics of proteins in cheonggukjang (fermented unsalted soybean paste) prepared with various soybean cultivars. Food Science and Biotechnology, 21(1), 9-18.

Kuo, L.C., Cheng, W.Y., Wu, R.Y., Huang, C.J. and Lee K.T. (2006) Hydrolysis of black soybean isoflavone glycosides by Bacillus subtilis natto. Applied Microbiology and Biotechnolog, 73, 314-320.
Kuo, L.C., Wu, R.Y. and Lee, K.T. (2012)A process for high-efficiency isoflavone deglycosylation using Bacillus subtilis natto NTU-18. Appl. Microbiol. Biotechnol. 94(5), 1181-1188.

Lane, D.J., Pace, B., Olsen, G.J., Stahl, D.A., Sogin, M.L. and Pace, N.R. (1985) Rapid determination of $16 \mathrm{~S}$ ribosomal RNA sequences for phylogenetic analyses. Proceedings of the National Academy of Sciences of the United States of America, 82, pp. 6955-6959.

Lee, M., Hong, G.E., Zhang, H., Yang, C.Y., Han, K.H., Mandal, P.K. and Lee, C.H. (2015) Production of the isoflavone aglycone and antioxidant activities in black soymilk using fermentation with Streptococcus thermophilus S10. Food Science and Biotechnology, 24, 537-544.

Miura, T., Yuan, L., Sun, B., Fujii, H., Yoshida, M., Wakame, K. and Kosuna, K. (2002) Isoflavone aglycone produced by culture of soybean extracts with basidiomycetes and its antingiogenic activity. Bioscience Biotechnology and Biochemistry, 66, 2626-2631.

Mukhtar, H. and Haq, I. (2013) Comparative evaluation of agroindustrial byproducts for the production of alkaline protease by wild and mutant strains of Bacillus subtilis in submerged and solid state fermentation. The Scientific World Journal, 2013.

Murakami, H., Asakawa, T., Terao, J. and Matsushita, S. (1984) Antioxidative stability of tempeh and liberation of isoflavones by fermentation. Agricultural and BiologicalChemistry, 48, 2971-2975.

Otieno, D.O. and Shah, N.P. (2007) Endogenous betaglucosidase and beta-galactosidase activities from selected probiotic micro-organisms and their role in isoflavone biotransformation in soymilk. Journal of Applied Microbiology, 103, 910-917.

Pyo, Y.H., Lee, T.C. and Lee, Y.C. (2005) Effect of lactic acid fermentation on enrichment of antioxidant properties and bioactive isoflavones in soybean. Journal of Food Science, 70, S215-S220.

Raimondi, S., Roncaglia, L., De Lucia, M., Amaretti, A., Leonardi, A., Pagnoni, U.M. and Rossi, M. (2009) Bioconversion of soy isoflavones daidzin and daidzein by Bifidobacterium strains. Appl. Microbiol Biotechnol. 81(5), 943-950.

Raksha Rao, K., Vipin, A.V., Hariprasad, P., Anu Appaiah, K.A. and Venkateswaran, G. (2017) Biological detoxification of Aflatoxin B1 by Bacillus licheniformis CFR1. Food Control, 71, 234-241. 
Ren, M.Q., Kuhn, G., Wegner, J. and Chen, J. (2001) Isoflavones, substances with multi-biological and clinical properties. Eur. J. Nutr. 40(4), 135-146.

Schallmey, M., Singh, A. and Ward, O.P. (2004) Developments in the use of Bacillus species for industrial production. Canadian Journal of Microbiology, 50, 1-17.

Shin, E.C., Lee, J.H., Hwang, C.E., Lee, B.W., Kim, H. T., Ko, J.M., Baek, I.Y., Shin, J.H., Nam, S.H., Seo, W.T. and Cho, K.M. (2014) Enhancement of total phenolic and isoflavone-aglycone contents and antioxidant activities during Cheonggukjang fermentation of brown soybeans by the potential probiotic Bacillus subtilis CSY191. Food Science and Biotechnology, 23, 531-538.

Shon, M.Y., Lee, J., Choi, J.H., Choi, S.Y., Nam, S.H., Seo, K.I., Lee, S.W., Sung, N.J. and Park, S.K. (2007) Antioxidant and free radical scavenging activity of methanol extract of chungkukjang. Journal of Food Composition and Analysis, 20, 113-118.

Stanbury, P.F., Whitaker, A. and Hall, S.J. (1995) CHAPTER 3 - The Isolation, Preservation and Improvement of Industrially Important Microorganisms. In: "Principles of Fermentation Technology" $2^{\text {nd }}$ ed., pp. 35-91. Amsterdam: Pergamon.

Tsangalis, D., Ashton, J.F., McGill, A.E.J. and Shah, N.P. (2002) Enzymic transformation of isoflavone phytoestrogens in soymilk by $\beta$-Glucosidaseproducing bifidobacteria. Journal of Food Science, 67, 3104-3113.

Vong, W.C., Au Yang, K.L. and Liu, S.Q. (2016) Okara (Soybean residue) biotransformation by yeast Yarrowia lipolytica. International Journal of Food Microbiology, 235, 1-9.
Wei, Q.K., Chen, T.R. and Chen, J.T. (2008) Use of Bacillus subtilis to enrich isoflavone aglycones in fermented natto. Journal of the Science Food and Agriculture, 88, 1007-1011.

Wołosowska, S. and Synowiecki, J. (2004) Thermostable $\beta$-glucosidase with a broad substrate specifity suitable for processing of lactosecontaining products. Food Chemistry, 85, 181-187.

Xiao, Y., Wang, L., Rui, X., Li, W., Chen, X., Jiang, M. and Dong, M. (2015) Enhancement of the antioxidant capacity of soy whey by fermentation with Lactobacillus plantarum B1-6. Journal of Functional Foods, 12, 33-44.

Yamabe, S., Kobayashi-Hattori, K., Kaneko, K., Endo, H. and Takita, T. (2007) Effect of soybean varieties on the content and composition of isoflavone in rice-koji miso. Food Chemistry, 100, 369-374.

Yang, S., Wang, L., Yan, Q., Jiang, Z. and Li, L. (2009) Hydrolysis of soybean isoflavone glycosides by a thermostable $\beta$-glucosidase from Paecilomyces thermophila. Food Chemistry, 115, 1247-1252.

Yin, L.J., Li, L.T., Li, Z.G., Saito, M. and Tatsumi, E. (2004) Change in isoflavone contents and composition of sufu (fermented tofu) during manufacturing. Food Chemistry, 87, 587-592.

Yin, L.J., Li, L.T., Liu, H., Saito, M. and Tatsumi, E. (2005) Effects of fermentation temperature on the content and composition of isoflavones and $\beta$-glucosidase activity in sufu. Bioscience Biotechnology and Biochemistry, 69, 267-272.

Zhou, C., Xue, Y. and Ma, Y. (2017) Characterization and overproduction of a thermo-alkaline pectate lyase from alkaliphilic Bacillus licheniformis with potential in ramie degumming. Process Biochemistry, 54, 49-58. 


\title{
تقييم إنتاج الجينيستين والدايذزين بواسطة بعض العزلات البكترية والفطرية المحلية \\ أسماء إبراهيم الثاذلى، عزة محمد نورالدين، نيفين أحمد إبراهيم، نيرة أحمد محمد عبدالواحد، أحمد عاطف البيه، يسيرية

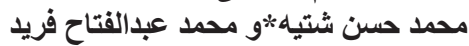 قسم كيمياء المنتجات الطبيعية والميكروبية ـ المركز القومى للبحوث و*قنم الميكروبيولوجى - جامعة عين شمس ـ القاهره ـ مصر.
}

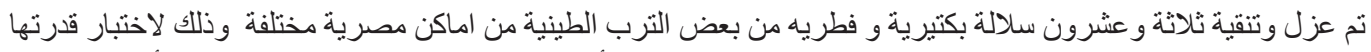

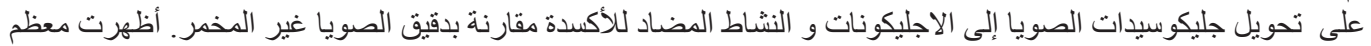

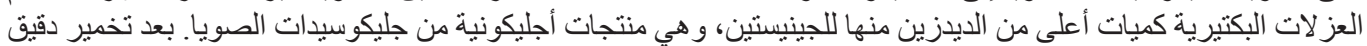

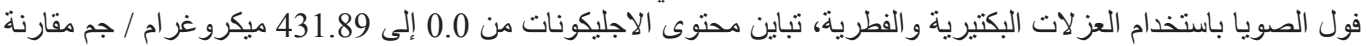

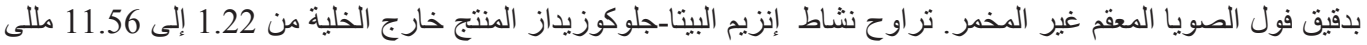

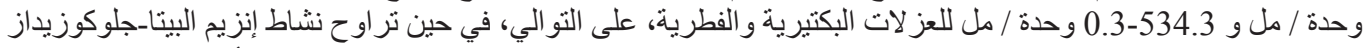

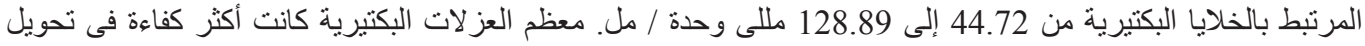

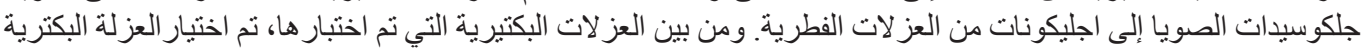

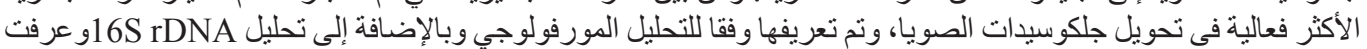

Bacillus licheniformis NRC24 بأنهات
\end{abstract}

